\title{
Ilmu Pengetahuan dan Teknologi Menurut Pandangan Islam
}

\author{
Ir. Hj. Andi Ombong Sapada, M.Si. \\ Muhammad Arsyam, S.Pd., M.Pd. \\ Sekolah Tinggi Agama Islam Darud Dakwah wal Irsyad (STAI DDI) Kota Makassar \\ Email: andiosapada@gmail.com \\ Email: arsyam0505@gmail.com
}

\begin{abstract}
Abstrak
Di zaman sekatrang ini, kemajuan tidak bisa dibendung lagi. Dunia semakin maju dan semakin modern. Dengan kemajuan tersebut, ilmu pengetahuan dan teknologi semakin maju dan berkembang bahkan semakin modern. Dalam islam, ilmu pengetahuan dan teknologi adalah suatu keharusan dan harus sesuai dengan pandangan islam. Ilmu pengetahuan dan teknologi tanpa pandangan islam, maka akan terjadi kekacauan baik secara fisik maupun secara nonfisik.
\end{abstract}

Kata Kunci: Ilmu Pengetahuan, Teknologi, Pandangan Islam

\section{Pendahuluan}

Puji syukur kehadirat Allah SWT senantiasa memberikan kesempatan dan kesehatan dalam aktivitas keseharian kita. Amin

Salam dan Taslim atas Baginda Rasulullah Muhammad SAW atas segalah risalah dan petunjuk yang telah dibawahnya.

Peran Islam dalam perkembangan iptek pada dasarnya ada dua. Pertama, menjadikan Aqidah Islam sebagai paradigma ilmu pengetahuan. Paradigma inilah yang seharusnya dimiliki umat Islam, bukan paradigma sekuler seperti yang ada sekarang (Zuhdi, 2015). Paradigma Islam ini menyatakan bahwa Aqidah Islam wajib dijadikan landasan pemikiran (qa'idah fikriyah) bagi seluruh ilmu pengetahuan (Ilmi, 2012). Ini bukan berarti menjadi Aqidah Islam sebagai sumber segala macam ilmu pengetahuan, melainkan menjadi standar bagi segala ilmu pengetahuan. Maka ilmu pengetahuan yang sesuai dengan Aqidah Islam dapat diterima dan diamalkan, sedang yang bertentangan dengannya, wajib ditolak dan tidak boleh diamalkan. Kedua, menjadikan Syariah Islam (yang lahir dari Aqidah Islam) sebagai standar bagi pemanfaatan iptek dalam kehidupan sehari-hari (Ainiyah, 2013). Umat Islam boleh memanfaatkan iptek jika telah dihalalkan oleh Syariah Islam. Sebaliknya jika suatu aspek iptek dan telah diharamkan oleh Syariah, maka tidak boleh umat Islam memanfaatkannya, walau menghasilkan manfaat sesaat memenuhi kebutuhan manusia (Arsyam, M. 2020).

\section{Pembahasan}

(Disampaikan Pada Ceramah Jamaah Majelis Taklim Masjid Nurul Ismi Mamoa, 28 Mei 2020) 
Kemajuan ilmu pengetahuan dan teknologi dunia, yang kini dipimpin oleh perdaban barat satu abad terakhir ini, mencengangkan banyak orang di berbagai penjuru dunia (Nahadi, M., Sarimaya, F., \& Rosdianti, S. R. 2011). Kesejahteraan dan kemakmuran material (fisikal) yang dihasilkan oleh perkembangan iptek modern membuat orang lalu mengagumi dan meniru- niru gaya hidup peradaban barat tanpa dibarengi sikap kritis trhadap segala dampak negatif yang diakibatkanya (Zahro, 2015). Pada dasarnya kita hidup di dunia ini tidak lain untuk beribadah kepada Allah SWT. Ada banyak cara untuk beribadah kepada Allah SWT seperti sholat, puasa, dan menuntut ilmu. Menuntut ilmu ini hukumnya wajib. Seperti sabda Rasulullah SAW: “ menuntut ilmu adalah sebuah kewajiban atas setiap muslim laki-laki dan perempuan". Ilmu adalah kehidupanya islam dan kehidupanya keimanan.

\section{Pengertian iptek dan kaitannya dengan Islam}

Untuk memperjelas, akan disebutkan dulu beberapa pengertian dasar. Ilmu pengetahuan (sains) adalah pengetahuan tentang gejala alam yang diperoleh melalui proses yang disebut metode ilmiah (scientific method) (Aji, 2017). Sedang teknologi adalah pengetahuan dan keterampilan yang merupakan penerapan ilmu pengetahuan dalam kehidupan manusia seharihari. Perkembangan iptek, adalah hasil dari segala langkah dan pemikiran untuk memperluas, memperdalam, dan mengembangkan iptek

Peran Islam dalam perkembangan iptek, adalah bahwa Syariah Islam harus dijadikan standar pemanfaatan iptek (Hasibuan, 2014). Ketentuan halal-haram (hukum-hukum syariah Islam) wajib dijadikan tolok ukur dalam pemanfaatan iptek, bagaimana pun juga bentuknya. Iptek yang boleh dimanfaatkan, adalah yang telah dihalalkan oleh syariah Islam. Sedangkan iptek yang tidak boleh dimanfaatkan, adalah yang telah diharamkan syariah Islam.

\section{Kewajiban mencari ilmu}

Pada dasarnya kita hidup didunia ini tidak lain adalah untuk beribadah kepada Allah. Tentunya beribadah dan beramal harus berdasarkan ilmu yang ada di Al-Qur'an dan Al-Hadist (Wiartha, 2017). Tidak akan tersesat bagi siapa saja yang berpegang teguh dan sungguh-sungguh perpedoman pada Al-Qur'an dan Al-Hadist. Disebutkan dalam hadist, bahwasanya ilmu yang wajib dicari seorang muslim ada, sedangkan yang lainnya akan menjadi fadhlun (keutamaan). Ketiga ilmu tersebut adalah ayatun muhkamatun (ayat-ayat Al-Qur'an yang menghukumi), sunnatun qoimatun (sunnah dari Al-hadist yang menegakkan) dan faridhotun adilah (ilmu bagi waris atau ilmu faroidh yang adil). Dimasa pandemi covid-19, terjadi transformasi dibidang agama khususnya di bidang dakwah (Sainuddin, 2020). Dari transformasi inilah, maka sosial media menjadi salah satu trand dalam mendapatkan pendidikan bagi keluarga khususnya 
pendidikan agama. Dalam pendidikan agama, dakwah menjadi salah satu yang dilakukan (Sainuddin, 2020).

Dalam sebuah hadist rasulullah bersabda, "mencari ilmu itu wajib bagi setiap muslim, dan orang yang meletakkan ilmu pada selain yang ahlinya bagaikan menggantungkan permata dan emas pada babi hutan."(HR. Ibnu Majah dan lainya)

Juga pada hadist rasulullah yang lain,"carilah ilmu walau sampai ke negeri cina ”. Dalam hadist ini kita tidak dituntut mencari ilmu ke cina, tetapi dalam hadist ini rasulullah menyuruh kita mencari ilmu dari berbagai penjuru dunia. Walau jauh ilmu haru tetap dikejar.

Kadang-kadang orang lupa dalam mendidik anaknya, sehingga lebih mengutamakan ilmu-ilmu umum daripada ilmu agama (Kosim, 2015). Maka anak menjadi orang yang buta agama dan menyepelekan kewajiban-kewajiban agamanya. Dalam hal ini orang tua perlu sekali memberikan bekal ilmu keagamaan sebelum anaknya mempelajari ilmu-ilmu umum.

Dalam hadist yang lain Rasulullah bersabda, "sedekah yang paling utama adalah orang islam yang belajar suatu ilmu kemudian diajarkan ilmu itu kepada orang lain."(HR. Ibnu Majah)

Maksud hadis diatas adalah lebih utama lagi orang yang mau menuntut ilmu kemudian ilmu itu diajarkan kepada orang lain. Inilah sedekah yang paling utama dianding sedekah harta benda. Ini dikarenakan mengajarkan ilmu, khususnya ilmu agama, berarti menenan amal yang muta'adi (dapat berkembang) yang manfaatnya bukan hanya dikenyam orang yang diajarkan itu sendiri, tetapi dapat dinikmati orang lain.

\section{Keutamaan orang yang berilmu}

Orang yang berilmu mempunyai kedudukan yang tinggi dan mulia di sisi Allah dan masyarakat. Al-Quran menggelari golongan ini dengan berbagai gelaran mulia dan terhormat yang menggambarkan kemuliaan dan ketinggian kedudukan mereka di sisi Allah SWT (Andriani, 2016).

Dalam surat ali Imran ayat ke-18, Allah SWT berfirman: "Allah menyatakan bahwasanya tidak ada Tuhan melainkan Dia (yang berhak disembah), Yang menegakkan keadilan. Para Malaikat dan orang- orang yang berilmu (juga menyatakan yang demikian itu). Tak ada Tuhan melainkan Dia (yang berhak disembah), Yang Maha Perkasa lagi Maha Bijaksana". Dalam ayat ini ditegaskan pada golongan orang berilmu bahwa mereka amat istimewa di sisi Allah SWT . Mereka diangkat sejajar dengan para malaikat yang menjadi saksi Keesaan Allah SWT. Peringatan Allah dan Rasul-Nya sangat keras terhadap kalangan yang menyembunyikan kebenaran/ilmu, sebagaimana firman-Nya: "Sesungguhnya orang-orang yang menyembunyikan apa yang telah Kami turunkan berupa keterangan-keterangan (yang jelas) dan 
petunjuk, setelah Kami menerangkannya kepada manusia dalam Al-Kitab, mereka itu dilaknati Allah dan dilaknati pula oleh semua (mahluk) yang dapat melaknati." (Al-Baqarah: 159)

\section{Kesimpulan}

Perkembangan iptek adalah hasil dari segala langkah dan pemikiran untuk memperluas, memperdalam, dan mengembangkan iptek.Dari uraian di atas dapat dipahami, bahwa peran Islam yang utama dalam perkembangan iptek setidaknya ada 2 (dua). Pertama, menjadikan Aqidah Islam sebagai paradigma pemikiran dan ilmu pengetahuan. Kedua, menjadikan syariah Islam sebagai standar penggunaan iptek .

\section{Daftar Pustaka}

Ainiyah, N. (2013). Pembentukan karakter melalui pendidikan agama Islam. Al-Ulum, 13(1), 2538.

Aji, S. D. (2017, August). Etnosains dalam membentuk kemampuan berpikir kritis dan kerja ilmiah siswa. In Prosiding SNPF (Seminar Nasional Pendidikan Fisika) (pp. 7-11).

Andriani, A. (2016). Munculnya Lembaga Pendidikan Islam. FALASIFA: Jurnal Studi Keislaman, 7(2), 285-298.

Arsyam, M. (2020, August 3). PENGARUH KEMAMPUAN SUPERVISIONAL KEPALA SEKOLAH DAN PERAN KOMITE SEKOLAH TERHADAP KINERJA GURU SMA NEGERI DI KOTA MAKASSAR. https://doi.org/10.31219/osf.io/j84ew

Hasibuan, N. (2014). Peran Islam dalam perkembangan teknologi pendidikan. LOGARITMA: Jurnal Ilmu-ilmu Kependidikan dan Sains, 2(1), 108-126.

Ilmi, Z. (2012). Islam Sebagai Landasan Perkembangan Ilmu Pengetahuan dan Teknologi. LENTERA, 14(1 JUNI).

Kosim, M. (2015). PEMIKIRAN PENDIDIKAN ISLAM IBN KHALDUN DAN RELEVANSINYA DENGAN SISDIKNAS. Jurnal Tarbiyah, 22(2).

Sainuddin, I. H., S. (2020, July 19). Transformasi Dakwah di Masa Pandemi Covid-19. https://doi.org/10.31219/osf.io/nakhy

Sainuddin, I. H., S. (2020, July 27). Dakwah di Era Sosial Media. https://doi.org/10.31219/osf.io/2jxny

WIARTHA, H. A. P. (2017). PERAN ORANG TUA DALAM MENANAMKAN NILAI-NILAI AGAMA ISLAM DI DESA WINONG KALIDAWIR TULUNGAGUNG.

Zahroh, L. (2015). Integrasi iman dan ilmu pengetahuan dalam pendidikan Islam (kajian QS AlMujadalah ayat 11, QS Al-Taubah ayat 122, dan QS Al-Isra ayat 36) (Doctoral dissertation, UIN Walisongo). 
Zuhdi, M. H. (2015). PARADIGMA FIQH AL-BI'AH BERBASIS KECERDASAN NATURALIS: TAWARAN HUKUM ISLAM TERHADAP KRISIS EKOLOGI. $A l$ 'Adalah, 12(2), 771-784. 